\title{
11: 118471387-118469797
}

National Cancer Institute

\section{Source}

National Cancer Institute. 11:118471387-118469797. NCI Thesaurus. Code C42453.

Physical location of H2AX_Gene 